\title{
The Value of Javanese Culture in Adipati Karna Puppet Character
}

\author{
Suyatno $^{1, *}$, Basuki Sumartono ${ }^{2}$ \\ ${ }^{1,2}$ University Centre of Excellence Javanology for Javanese Traditions, Universitas Sebelas Maret, Surakarta, \\ Indonesia \\ "Corresponding author. Email: suyatno_sasda@staff.uns.ac.id
}

\begin{abstract}
Wayang is the most popular product of Javanese culture from the past to this day. In the characters there are many values that are the core of Javanese culture, one of which is the basic value of politeness. The form of research chosen is descriptive qualitative by using a politeness approach to the character of the characters and applying the concept of cultural semiotics. Data transcripts were carried out carefully and various things related to the problem were recorded. The collected textual facts are then interpreted proportionally based on symbols and symbols to get the expected value conclusions. The results show that Adipati Karna is an idol figure of Javanese society. Because it has superior characteristics, including being able to decode.
\end{abstract}

Keywords: Politeness, Javanese, Culture, Puppet

\section{INTRODUCTION}

In Javanese culture we recognize the term politeness. Politeness plays an important role in every social interaction. Politeness is an attitude of being able to place oneself in a social position, and it is also an acknowledgment of one's existence in a social position. Being able to put yourself and selfrecognition in a social position is a value [1] [10]. so it can be said that politeness is a value. The value of politeness is reflected in social behavior in society, as well as in Javanese literary works, including puppet literature [4]. This paper tries to analyze the politeness value of a character named Adipati Karna in puppet literature. The Adipati Karna character is interesting to study, because it contains controversy, where one side is the family and the other is the enemy. However, even so, the Adipati Karna character still puts forward politeness in his life. The question is what politeness values are contained in the Adipati Karna character?

The formal object in this study is value. Values are the mainstay of axiological studies. Axiology examines the value or value of something [9]. The essence of value is the quality that is contained in a thing so that it becomes the goal and object of interest. Values provide motivation for human behavior so that humans try to fight for it, and once achieved, try to defend it. Value is a quality that is contained in something, a quality that is not real. Value can also mean "excellence", which is something that is valued, highly regarded and as a good thing. Value is contrasted with no value or negative value. - Value is a "trait" and value can influence human actions to choose and further guide himself and others to do actions. An action that is valued is an action that is intended. - Talking about values, not just talking about something theoretically but also practically. If someone believes that something or condition is good, important or useful, then there is a tendency for him to want to achieve or possess that characteristic and when it is achieved he wants to maintain it and then try to make it happen in life" [6].

Material object is the subject of study to be discussed based on a certain point of view. In this paper the object of study is politeness. Politeness is a product of Javanese culture. In this study, what is used as the object of study is the politeness of a character in puppet literature, namely Adipati Karna in the play Kresna Duta played by a puppeteer Ki Narto Sabdo.

\subsection{Politeness}

Politeness is a human attitude to place himself in a social position. Doing politeness means acknowledging his existence in social status. Putting oneself in a social position and acknowledging its existence in that social status is the value of one's politeness. Here there is something valuable, something valuable, something useful in a culture, 
namely about placing oneself and acknowledging one's existence in social interactions, which means politeness. Politeness comes from the word santun which means smooth or good [3], [8].

\subsubsection{Biography of Adipati Karna}

When Kunti was still a teenager, she studied at the Resi Druwasa, then by Resi Druwasa was given a lesson or a kind of magic / mantra called "Aji Konta Wekasing Rasa Sabda Tunggal Tanpa Lawan". The greatness of this mantra, if it is "wateg" (read solemnly in the soul) can bring out the desired deity. At one point he forgot, namely when he was taking a bath, Kunti or Dewi Kunti read the spell / mantra "Aji Konta Wekasing Rasa Tunggal Tanpa Lawan" so that in Heaven there was a commotion. The mantra is meant to bring a God from Heaven. Even though at that time the gods were busy, only God of Surya was unemployed, so He was sent down to earth to meet someone who brought him. Next, God of Surya met Kunti, and there was a dialogue between the two about the purpose of bringing the God. Kunti replied that reading the spell / mantra was not intentional. However, God of Surya remained in his position, saying that he came down to earth that there must be a result. In summary, Kunti conceived and gave birth to a boy who was named Karna Basusena, and then to protect the good name of the kingdom, Karna Basusena, who was still a baby, was put into "kendhaga wreksa" and carried away in the river.

Adirata, a coachman from the country of Hastina, finds a baby who is washed up in a river. With his wife named Bibi Nada, the baby was nurtured until he became a Duke of Angga who was under the Hastina Kingdom. And, in addition to being a Duke in the Hastina kingdom, Karna was appointed Commander of War. When the Baratayuda war (the war between the Pandawa and Kurawa) took place, Adipati Karna still sided with the Kurawas and did not side with the Pandawa, even though the Pandawa were his own brothers [2], [7].

\section{METHODS}

First, the story of the puppet kresna duta, played by puppeteer ki Narto Sabdo, was listened to carefully and thoroughly. Second, the story in the play which is used as the source of the data is transcribed, meaning that data that was previously in the form of audio is converted into written data. Third, data display and data reduction. The data that has been collected are grouped into several groups of understanding, then analyzed so that some values of the politeness of the Adipati Karna figure are found. Data analysis is in the form of a description to be a clear and valid understanding. Fifth, conclusions.

\section{THE VALUES IN THE ACTIONS OF THE ADIPATI KARNA CHARACTER}

The things that are interesting to study from Adipati Karna's actions are: when before the Baratayuda war, there was a conflict between Adipati Karna and Prabu Salya who was actually the father-inlaw, the second was during the meeting between Adipati Karna and her mother Dewi Kunti.

\section{a. Can Read Pasemon}

When Prabu Duryudana his soul would soften when he received suggestions from Resi Bisma, Pandhita Durna, Patih Sengkuni, and Prabu Salya about the existence of the kingdoms of Hastina and Ngendraprasta and their colonies; then Adipati Karna as the Commander of the War put forward a proposal, even though he was not asked for his opinion, the content and essence of which Prabu Duryudana did not deserve to let go of the Hastina Kingdom and its colonies if it did not go through war. Even worse, when he heard the suggestion of a person who was worshiped, a respected person who would give his kingdom if the whole Kingdom of Hastina and Ngendrapasta and their colonies were given to the Pandawa. The suggestion was King Salya, the fatherin-law of Adipati Karna. Adipati Karna said that no one willingly gives his kingdom, likened to "sadumuk bathuk sanyari bumi", how come there are parents who pretend to give their kingdom, and that is impossible.

Hearing the adipati karna's words, king salya, although not directly appointed, then prabu salya " waspadeng semu", or carefully understood what was actually meant and to whom the utterance was addressed. So that prabu salya could not hold back his anger, so that his anger was poured out on adipati karna who is actually a son-in-law.

If we look at Prabu Salya's angry expression which was addressed directly to Adipati because of this, Adipati Karna did not answer at all. This means that Adipati Karna can refrain from answering to Prabu Salya. So from this incident what is found is "false alert" or can read signs; and can hold back when there is a dispute at a meeting. If modesty is an attitude, humans place themselves in a social position. Then, doing politeness means acknowledging his existence in social status. In this incident Adipati Karna could position himself as the Commander of War who had the task of upholding the existence of the kingdom, including providing support to the ruling king. Apart from that Adipati Karna did not answer Prabu Salya's anger directed at him because Adipati 
Karna was aware of his social position, that he was talking to parents who were also father-in-law who were obliged to respect him. Why is it obligatory to respect the parents-in-law, because the in-laws are the ones who give pleasure to be matched with their daughter. So two things were found, namely " waspadeng semu" and restraint.

\section{b. Respect for Parents (Mother)}

When Prabu Kresna came to the country of Hastina as an ambassador for the Pandawa to claim the return of the Hastina state to the Pandawa, which at that time coincided with the complete meeting, Adipati Karna quietly escaped from the complete meeting. When the meeting was over, Prabu Kresna did not immediately return to the land of Wirata, but tried to meet Adipati Karna by following the tracks of the train's wheels, which finally met him on the way. After the meeting between King Kresna and Adipati Karna was over, Adipati Karna did not immediately return to the kingdom of Angga, but tried to meet his mother Dewi Kunti for the first and last time.

Adipati Karna knows and is aware of his life history which since infancy was not taken care of by his mother named Dewi Kunti, but instead was nurtured and raised by Adirata with his wife named Nada, until he got the position of king in Angga who was under the rule of hastina whose king was named Prabu Duryudana. Adipati Karna actually felt disappointed because she was not being cared for like her siblings, the Pandawa, it was stated that when she met Dewi Kunti, Adipati Karna always avoided her. However, when he fulfills the obligations of a knight who is also a war commander, when he meets his mother the first thing he does is "sungkem", a form of respect for someone who deserves to receive. The two Adipati Karna asked for a prayer of blessing to carry out the duties of a knight to fight against the enemy. However, Kunti, before giving his blessing to be victorious in battle, first asked who his opponent was. Adipati Karna honestly said that his opponents were his own younger siblings, namely the Pandawa.

If we look closely, Adipati Karna's actions towards her mother named Dewi Kunti can be found that even though she feels disappointed because of her mother's actions, Adipati Karna still tries to find and meet her and give respect, so there is respect for parents here. Then Adipati Karna admitted although with a heavy heart that the one who would become his enemy in the Great Baratayuda war would be his own brother. If modesty is an attitude, humans place themselves in a social position. Then, doing politeness means acknowledging his existence in social status. Then Adipati Karna can put himself in the relationship between the child and the mother that is obliged to be respected, then no matter how hard being honest and saying what it is is a chivalrous attitude that must be conveyed to parents in this case to his own mother. So from this description it can be found that politeness contains elements of respect and honesty.

\section{CONCLUSION}

In puppet literature contains elements of the value of politeness as stated in the character Adipati Karna before the outbreak of the Baratayuda war. In politeness, four values are found, including " waspadeng semu" of being able to read signs, being able to hold back, respect and honesty.

\section{AUTHORS' CONTRIBUTIONS}

Authors writes all from introduction to conclusion

\section{ACKNOWLEDGMENTS}

Acknowledgements and appreciation to University Centre of Excellence Javanologi for Javanese Traditions Universitas Sebelas Maret for funding the publication.

\section{REFERENCES}

[1] Bertens, K. “Etika”. Jakarta: Gramedia Pustaka Utama. 2011.

[2] https://id.wikipedia.org/wiki/Adirata

[3] https://kbbi.web.id/santun

[4] Magnis-Suseno, Franz. "Etika Jawa". Jakarta: Gramedia. 1984.

[5] Magnis-Suseno, Franz. "Etika Dasar: Masalahmasalah Pokok Filsafat Moral. Yogyakarta: Kanisius. 1987.

[6] Mudhofir, Ali. "Kamus Etika". Yogyakarta: Pustaka Pelajar. 2009

[7] Sabdo, Narto. [19..]. "Kresna Duta”. Rekaman dalam bentuk file Komputer, 7 Maret 2010

[8] Satoto, Sudiro dkk. "Ki Narto Sabdo (Hidup, Idealisme dan Ajarannya)". Sukoharjo: Cendrawasih Asri. Surakarta: Pusat Studi Javanologi (Institut Javanologi), LPPM UNS. 2012.

[9] Suyatno. "Pemikiran Sukarno tentang Nasionalisme Dalam Perspektif Aksiologi: Kontribusinya Bagi Pendidikan Karakter Bangsa. 2016.

[10] Mohamad, B., Zulkepli Hew, J., Ismail, A. R., \& Abu Bakar, H. "The work values of Malaysian graduates: Scale development and validation." Journal of Advanced Research in Dynamical and Control Systems, 11(5), 709-720. 2019 